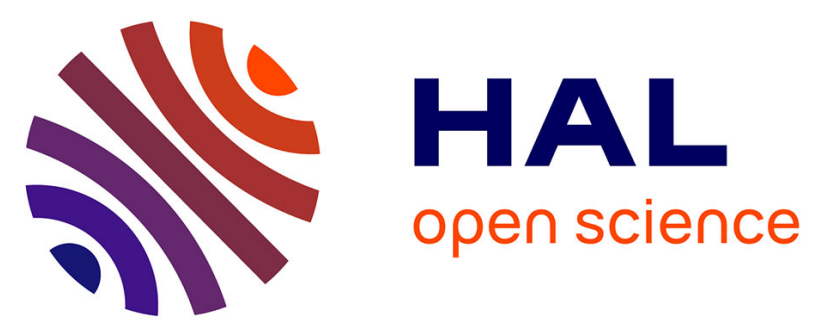

\title{
Graphiola fimbriata: the first species of Graphiolaceae (Exobasidiales, Basidiomycota) described only based on its yeast stage
}

Shaghayegh Nasr, Matthias Lutz, Mohammad Ali Amoozegar, Véronique Eparvier, Didier Stien, Seyed Abolhassan Shahzadeh Fazeli, Andrey Yurkov

\section{To cite this version:}

Shaghayegh Nasr, Matthias Lutz, Mohammad Ali Amoozegar, Véronique Eparvier, Didier Stien, et al.. Graphiola fimbriata: the first species of Graphiolaceae (Exobasidiales, Basidiomycota) described only based on its yeast stage. Mycological Progress, 2019, 18 (3), pp.359-368. 10.1007/s11557-018-1450-1 . hal-02342188

\section{HAL Id: hal-02342188 \\ https://hal.sorbonne-universite.fr/hal-02342188}

Submitted on 31 Oct 2019

HAL is a multi-disciplinary open access archive for the deposit and dissemination of scientific research documents, whether they are published or not. The documents may come from teaching and research institutions in France or abroad, or from public or private research centers.
L'archive ouverte pluridisciplinaire HAL, est destinée au dépôt et à la diffusion de documents scientifiques de niveau recherche, publiés ou non, émanant des établissements d'enseignement et de recherche français ou étrangers, des laboratoires publics ou privés. 
3

4 Shaghayegh Nasr $^{1}$, Matthias Lutz ${ }^{2}$, Mohammad Ali Amoozegar ${ }^{1,3}$, Véronique Eparvier ${ }^{4}$, Didier

\section{Graphiola fimbriata sp. nov. is the first anamorphic species of Graphiolaceae}

\section{(Exobasidiales, Basidiomycota)}

Stien $^{4,5}$, Seyed Abolhassan Shahzadeh Fazeli ${ }^{1,6}$, Andrey Yurkov ${ }^{7}$

${ }^{1}$ Microorganisms Bank, Iranian Biological Resource Center (IBRC), ACECR, Tehran, Iran; email: nasr@ibrc.ir; shaghayegh2963@yahoo.com

${ }^{2}$ Plant Evolutionary Ecology, Institute of Evolution and Ecology, University of Tübingen, Auf der Morgenstelle 5, D-72076 Tübingen, Germany; e-mail: matthias.lutz@uni-tuebingen.de

${ }^{3}$ Extremophiles Laboratory, Department of Microbiology, Faculty of Biology and Center of Excellence in Phylogeny of Living Organisms, College of Science, University of Tehran, Tehran, Iran; e-mail: amoozegar@ut.ac.ir

${ }^{4}$ French National Centre for Scientific Research, Institut de Chimie des Substances Naturelles, UPR 2301, Université Paris-Saclay, 1 avenue de la Terrasse, 91198 Gif-sur-Yvette, France; email: veronique.eparvier@cnrs.fr; $\underline{\text { didier.stien@cnrs.fr }}$

${ }^{5}$ Sorbonne Université, CNRS, Laboratoire de Biodiversité et Biotechnologie Microbienne, USR3579, Observatoire Océanologique, 66650 Banyuls-sur-Mer, France; e-mail: didier.stien@cnrs.fr

${ }^{6}$ Department of Molecular and Cellular Biology, Faculty of Basic Sciences and Advanced Technologies in Biology, University of Science and Culture, Tehran, Iran; e-mail: shfazeli@yahoo.com; fazeli@ibrc.ir

${ }^{7}$ Leibniz Institute DSMZ-German Collection of Microorganisms and Cell Cultures, Inhoffenstraße 7B, 38124 Brunswick, Germany; e-mail: andrey.yurkov@dsmz.de 


\section{Abstract}

31 The systematic position of three yeast strains isolated from a plant cell culture, a piece of termite

32 nest, and as a foliar endophyte of Coffea arabica, respectively, is evaluated using morphological,

33 physiological, and phylogenetical analyses. In culture, all three isolates produced white, pale

34 orange to pink colored colonies of cylindrical cells with monopolar budding and pseudohyphae.

35 Standard phenotypic, biochemical, physiological characterization and phylogenetic analyses of 36 the combined 26S rRNA gene (D1/D2 domains) and ITS region sequences showed the 37 conspecificity of these isolates and suggest their placement within the Exobasidiales 38 (Ustilaginomycotina) as a sister lineage of the sampled and sequenced Graphiola species. Here, 39 we describe this species as Graphiola fimbriata sp. nov. MycoBank MB 825077 (holotype: $40 \quad \mathrm{PC}^{\mathrm{T}}$; ex-type cultures: IBRC-M $30158^{\mathrm{T}}=\mathrm{CBS} 13945^{\mathrm{T}}=\mathrm{DSM} 104832^{\mathrm{T}}$ ). This is the first 41 anamorphic saprobic species described in the genus Graphiola. The description of the genus 42 Graphiola is therefore emended to allow species known only from a saprobic state.

43

44 Key words: 1 new taxon, Graphiola fimbriata sp. nov., Asexual state, Morphological

45 characterization, Phylogenetic analyses, Yeast

46

47

48

49

50

51

52 


\section{INTRODUCTION}

54 Fungi with yeast and yeast-like morphology are present within all three main lineages of

55 Basidiomycota, namely the subphyla Agaricomycotina, Pucciniomycotina, and

56 Ustilaginomycotina (Sampaio 2004, Boekhout et al. 2011, Kurtzman \& Boekhout 2017). Yeast

57 and filamentous taxa are often intermixed as revealed by recent phylogenetic studies (Liu et al.

58 2015a, 2015b, Wang et al. 2015a, 2015b, 2015c). With a few exceptions, a transition from

59 filamentous to yeast stage is often associated with the change from a parasitic to saprobic life

60 style (Begerow et al. 2017). The subphylum Ustilaginomycotina comprises a highly diverse

61 assemblage of fungi, including teliosporic plant pathogens, non-teliosporic plant pathogens,

62 anamorphic plant pathogens, as well as endophytic, lipophilic, saprobic, and zoophilic yeasts

63 (Begerow et al. 2014). The orders Malasseziales, Monilielalles, and Violaceomycetales include

64 exclusively yeast species of the genera Malassezia, Moniliella, and Violaceomyces, respectively

65 (Wang et al. 2014, Albu et al. 2015), while the remaining yeasts and yeast-like fungi are

66 scattered amongst the remaining orders of Ustilaginomycotina, with the exception of the

67 members of Doassansiales, Tilletiales and Uleiellales for which no yeasts have been discovered

68 so far.

69 The anamorphic saprobic members of Ustilaginomycotina have previously been classified

70 mainly in the polyphyletic genera Pseudozyma and Tilletiopsis (Begerow et al. 2000, Sampaio

71 2004, Kurtzman et al. 2011, 2015), and later in several monophyletic genera Acaromyces,

72 Farysizyma, Fereydounia, Jaminaea, Meira, and Sympodiomycopsis (Sugiyama et al. 1991,

73 Boekhout et al. 2003, Inácio et al. 2008, Sipiczki \& Kajdacsi 2009, Nasr et al. 2014). Sexual and

74 asexual morphs in Ustilaginomycotina were recently grouped together in order to unify the

75 taxonomy of plant parasites and species known only from their yeast states (Piątek et al. 2015, 
Wang et al. 2015a, Kijpornyongpan \& Aime 2016). As the result, several monophyletic genera

77 (Dirkmeia, Golubevia, Kalmanozyma, and Robbauera) were erected to accommodate species

78 previously classified in the genera Pseudozyma and Tilletiopsis (Wang et al. 2015a). The current

79 classification scheme recommends that each novel lineage not linked with a teleomorphic genus

80 or recognized anamorphic genus should be assigned to a new genus. The subphylum

81 Ustilaginomycotina comprises the least number of yeast and yeast-like species (71) compared to

82 the two other subphyla of Basidiomycota (Wang et al. 2015a). However, studies that involved

83 environmental sequencing suggest a much greater, unexplored diversity of fungi in this group

84 (e.g., Richards et al. 2012, Nasanit et al. 2015, Dunthorn et al. 2017, Jimu et al. 2017).

85 In the course of independent studies two yeast strains have been isolated. The first culture (PC1)

86 was isolated in the Iranian Biological Resource Center (IBRC) from a contaminated plant

87 culture, and the second isolate (SNB-CN72) was obtained from a nest of the termite species

88 Nasutitermes corniger harvested in Rémire-Montjoly, French Guiana. Phylogenetic analyses of

89 the ITS region and the D1/D2 domains of the LSU rRNA gene placed the strains within

90 Graphiolaceae (Exobasidiomycetes, Exobasidiales) close to plant parasites of the genus

91 Graphiola, and revealed relatedness to a third yeast isolate (IBL 03150) reported by Posada et al.

92 (2007) and deposited in the CBS yeast collection of the Westerdijk Fungal Biodiversity Institute,

93 Utrecht, The Netherlands. Species in the plant pathogenic genus Graphiola are traditionally

94 circumscribed based on their host spectrum and symptoms, and nucleotide sequence data for

95 these fungi are rare (Wang et al. 2015a).

96 The aim of the study was to characterise the yeast-like isolates and determine their phylogenetic

97 placement, incorporating morphological, physiological, and molecular data yet available for 98 members of the genus Graphiola. 
MATERIALS AND METHODS

\section{Sample collection and isolation}

102 A plant cell culture of an unidentified plant species mixed with a yeast strain was obtained from

103 the plant bank section of the Iranian Biological Resource Center (IBRC) in 2013 (strain 104 designation: PC1). Another strain was isolated from a piece of Nasutitermes corniger nest 105 collected in Rémire-Montjoly, (Cayenne, French Guiana) in July 2011 (strain designation: SNB106 CN72; Nirma et al. 2013, 2015). A third strain was obtained from the CBS yeast collection of the 107 Westerdijk Fungal Biodiversity Institute, Utrecht, The Netherlands (original strain designation: 108 IBL 03150). It was isolated as foliar endophyte of Coffea Arabica (Posada et al. 2007). 109 Designations and GenBank accession numbers of the yeast strains used in this study are given in 110 Table 1.

111 Cultures were maintained on YPG agar medium $(0.5 \%$ yeast extract, $1 \%$ peptone, $2 \%$ glucose, $1122 \%$ agar, w/v) at $25{ }^{\circ} \mathrm{C}$ during experiments.

113 To expand the ITS sequence sampling for molecular phylogenetic analyses a specimen of the 114 plant parasitic genus Graphiola was additionally used and newly sequenced: Graphiola 115 phoenicis (Moug. ex Fr.) Poit. on Phoenix reclinata Jacq., South Africa, Kwa Zulu-Natal, 116 Durban, Yellowwood Park, Kenneth Stainbank Nature Reserve, 14 Feb. 2012, leg. A.R. Wood 117 883, KR-M-0042315.

119 Morphological examination

120 Colony morphology images were taken using a stereo microscope coupled with the Nikon zoom 121 digital camera. In addition, scanning electron microscopy was performed on the isolate using a 
122 VEGA3-TESCAN SEM instrument (Van Wyk \& Wingfield 1994). Briefly, the cells were fixed 123 in $3.0 \%, 0.1 \mathrm{M}, \mathrm{pH} 7.0$ sodium phosphate-buffered glutaraldehyde for $3 \mathrm{~h}$ at room temperature, 124 followed by $1 \mathrm{~h}$ fixation in $2 \%$ osmium tetroxide. The cells were dehydrated by increasing 125 ethanol concentrations $(30 \%, 50 \%, 70 \%, 90 \%$, and $96 \%)$ for $30 \mathrm{~min}$ and two 30 min washes in $126100 \%$ ethanol. The standard characterization of the yeast isolates was performed according to 127 methods described earlier (Barnett et al. 2000, Kurtzman et al. 2011). Assimilation of carbon and 128 nitrogen sources was carried out on solid and in liquid media, respectively.

\section{DNA extraction, PCR, and sequencing}

131 Nuclear DNA was extracted by the method of Hanna \& Xio (2006). For the Graphiola phoenicis 132 specimen, the genomic DNA was isolated directly from the herbarium specimen. The 5'-end 133 (D1/D2 region) of the nuclear large subunit ribosomal DNA (LSU) and the ITS 1 and ITS 2 134 regions of the nuclear rDNA including the 5.8S rDNA (ITS) were amplified and sequenced using 135 primer pairs NL1 (5'GCATATCAATAAGCGGAGGAAAAG-3') and NL4 (5' 136 GGTCCGTGTTTCAAGACGG3') (Kurtzman \& Robnett 1998) and ITS1 (5'137 TCCGTAGGTGAACCTGCGG-3') and ITS4 (5'-TCCTCCGCTTATTGATATGC-3') (White et 138 al. 1990), respectively. DNA sequences determined for this study were deposited in GenBank 139 (accession numbers are given in Figs $1 \& 2$ and in Table 1. Additional sequences of Graphiola 140 cylindrica and G. phoenicis were obtained from GenBank and the public catalogue of the NITE 141 Biological Resource Center collection (NBRC), Japan. 
144 To elucidate the phylogenetic position of the isolated strains their sequences were analysed 145 within a LSU and a concatenated ITS + LSU dataset. Since preliminary analyses and Blast 146 searches (Altschul et al. 1997) revealed an affinity of the stains to the order Exobasidiales (class

147 Exobasidiomycetes), the LSU dataset was reduced to members of the Exobasidiales and some 148 representatives of the Ustilaginomycetes were used as an outgroup. Isolates and clones, for 149 which only ITS sequences were available, were analysed in the LSU + ITS dataset. If present in 150 GenBank sequences of the respective type species were used. Additionally sequences of all 151 available brachybasidiaceous species and all available sequences clustering within the 152 Graphiolaceae including sequences from the Biological Resource Center, NITE, Japan were 153 added.

154 GenBank accession numbers of the sequences used for both the LSU and ITS+LSU dataset 155 (Begerow et al. 1997, 2001, 2002, Guo et al. 2001, Boekhout et al. 2003, Castlebury et al. 2005, 156 Stoll et al. 2005, Yasuda et al. 2005, 2006, Posada et al. 2007, Tanaka et al. 2008, Piepenbring et 157 al. 2010, 2012, Yuan et al. 2011, Jusino et al. 2015, Urbina et al. 2016) are given in Figs $1 \& 2$.

158 Sequence alignment was obtained independently for both the LSU dataset and the ITS and LSU 159 part of the ITS+LSU dataset using MAFFT 7.313 (Katoh \& Standley 2013) using the L-INS-i 160 option. To obtain reproducible results, manipulation of the alignments by hand as well as manual 161 exclusion of ambiguous sites were avoided as suggested by Gatesy et al. (1993) and Giribet and 162 Wheeler (1999), respectively. Instead, highly divergent portions of the alignments were omitted 163 using GBlocks 0.91b (Castresana 2000) with the following options for the LSU dataset: 164 'Minimum Number of Sequences for a Conserved Position': 20, 'Minimum Number of 165 Sequences for a Flank Position': 20, 'Maximum Number of Contiguous Non-conserved 166 Positions': 8, 'Minimum Length of a Block': 5, and 'Allowed Gap Positions' to 'With half', for 
167 the ITS part of the ITS+LSU dataset: $11 / 11 / 8 / 5 /{ }^{\prime} W$ ith half' and for the LSU part of the ITS+LSU 168 dataset: $12 / 12 / 8 / 5 /{ }^{\circ}$ With half'. After alignment the ITS and LSU part of the ITS+LSU dataset 169 were concatenated. The resulting alignments [LSU dataset: new number of positions: 591 (32\% 170 of the original 1801 positions), number of variable sites: 279; ITS+LSU dataset: new number of 171 positions: 1121 (34\% of the original 3264 positions), number of variable sites: 468] were used

172 for phylogenetic analyses using a Maximum Likelihood (ML) and a Bayesian Approach (BA) 173 following Vasighzadeh et al. (2014).

174 For the LSU dataset trees were rooted with the ustilaginomycetous species Urocystis ficariae and 175 Ustilago hordei, for the ITS+LSU dataset trees were rooted with the brachybasidiaceous species 176 Dicellomyces gloeosporus and Meira geulakonigii.

177 Metabolite profiling analysis was carried out for the three yeast strains and the results are 178 presented as supplementary data.

\section{RESULTS}

\section{Morphological examination}

182 Morphology of the strains IBL 03150, PC1, and SNB-CN72 showed no significant differences, 183 results are included in the species description.

184 Metabolite profiling with UHPLC-MS was carried out for the three yeast strains and the results 185 are provided in supplementary data. In the absence of metabolic data from closely related 186 species, the analysis of UHPLC-MS profiles was restricted to the tree strains. We observed that 187 the culture medium impacted more significantly on the profiles than the nature of the strain 188 (Supplementary data). Hierarchical clustering analyses $($ HCA) conducted on the $3(\mathrm{~N}) \times 29(\mathrm{X})$ 


\section{Yurkov"}

matrix of merged profiles showed that strains PC1 and IBL 03150 are more alike than SNBCN72 (Supplementary data).

\section{Phylogenetic analyses}

The different runs of the BA that were performed and the ML analyses yielded consistent topologies. To illustrate the results the consensus trees of one run of the BA of the LSU and the concatenated ITS+LSU dataset are presented (Figs 1 \& 2). Using the ustilaginomycetous species as outgroup in the LSU analysis, the clades in the phylogenetic tree were congruent to the families discussed in Begerow et al. (2014). In all analyses the sequences of the yeast isolates clustered within the Exobasidiales together with the sequence MF334501 from an uncultured fungus clone forming the sister lineage of the sampled Graphiola spp. of which the G. phoenicis cluster included several sequences of yeast isolates and uncultured fungus clones, respectively. The clade comprising Graphiola cylindrica, G. geonomae, G. phoenicis, and the yeast isolates received good statistical support (BA: 100\%, ML: 93\%). The yeast isolates branched first in the Graphiola clade and were placed sister to G. cylindrica, G. geonomae, and G. phoenicis. Combined ITS+LSU analyses (Fig. 2) revealed the same groups and relations including more sequences from Graphiola spp. as well as from the studied yeast isolates and uncultured fungus clones. The three strains shared identical LSU sequences and showed 5 variable positions (2 substitutions and 3 indels) in the ITS region.

\section{TAXONOMY}

Graphiola Poit., Ann. Sci. Nat. (Paris): 473 (1824) emend. "S. Nasr, M. Lutz, D. Stien \& A. 
212 According to the current genus concept of Graphiola (Piepenbring et al. 2012), the genus 213 comprises plant pathogens on palms (Arecaceae). Tubaki \& Yokohama (1971) and Oberwinkler 214 et al. (1982) obtained and studied Graphiola phoenicis in culture. They provided also the 215 diagnosis of this species, including morphological and physiological properties observed in 216 culture. Emendation of the diagnosis of the genus Graphiola is proposed to allow classification 217 of asexual, known only from a saprobic state yeast species in the genus.

218 Sexual reproduction is observed in some species. Fungi are dimorphic with a filamentous sexual 219 form parasitizing on plants and free-living saprobic yeast states. On malt extract, colonies are 220 white, pale orange to pink in color. Budding cells are present in culture. Colonies are white, pale 221 orange to pink in color. Ballistoconidia are not produced. Pseudohyphae may be present in 222 cultures. Fermentation is absent. DBB reaction is positive. Urease activity is positive.

224 Graphiola fimbriata S. Nasr, M. Lutz, D. Stien \& A. Yurkov, sp. nov. (Fig. 3)

225 MycoBank MB 825077

226 Etymology: Referring to the margin of the colonies.

227

228

Description: After three days on YPG agar at $25^{\circ} \mathrm{C}$, the cells are cylindrical, $1-2.5 \times 4-8.5 \mu \mathrm{m}$, 229 and occur single or in small chains. Budding is monopolar. After five days, the colony is white, 230 convex, and the margin is filiform. Pellicles are formed on liquid media. After one week at $25{ }^{\circ} \mathrm{C}$ 231 on MEA and Cornmeal agar, the slide culture undifferentiated pseudohyphae are formed. 232 Fermentation is negative. The following compounds are assimilated: glucose, sucrose, maltose, 233 trehalose, melezitose, D-xylose, raffinose, L-arabinose, D-mannitol, myo-inositol, D-ribose and 234 arbutin; assimilation of salicin, glycerol and cellobiose is weak. No growth occurs on galactose, 
235 lactose, L-rhamnose, melibiose, inulin, D-arabinose, soluble starch, ethanol, methanol, DL236 lactate, succinate, citrate and n-hexadecane. Sodium nitrate, potassium nitrate, L-lysine, 237 Ethylamine hydrochloride (variable) and cadaverine dihydrochloride (variable) are assimilated. 238 No growth occurs on glucosamine, imidazole, creatine or creatinine. Growth in vitamin-free 239 medium is positive. Growth at $15{ }^{\circ} \mathrm{C}, 25{ }^{\circ} \mathrm{C}, 30{ }^{\circ} \mathrm{C}$, and $34{ }^{\circ} \mathrm{C}$ is positive but not at $4{ }^{\circ} \mathrm{C}, 37^{\circ} \mathrm{C}$ 240 and $40{ }^{\circ} \mathrm{C}$. Growth occurs on YM agar supplemented with 5\% (w/v) NaCl, $10 \%$ (w/v) $\mathrm{NaCl}$ but 241 not on YM agar with 16\% (w/v) NaCl. Starch-like compounds are not produced. No growth 242 occurs on media supplemented with $0.01 \%$ and $0.1 \%$ cycloheximide, and $1 \%$ acetic acid. The 243 diazonium blue B reaction is weakly positive. Urease activity is positive.

244 Molecular characteristics: nucleotide sequences of ITS and LSU (D1/D2 domains) rDNA 245 sequences are deposited in GenBank (Table 1.)

246 Deposits: holotype, $\mathrm{PC}^{\mathrm{T}}\left(=\mathrm{IBRC}-\mathrm{M} 30158^{\mathrm{T}}\right)$ isolated as a contaminant of an unidentified plant 247 culture, preserved in a metabolically inactive state at the Iranian Biological Resource Centre, 248 Teheran (holotype), Iran. Ex-type cultures are deposited in the CBS yeast collection of the 249 Westerdijk Fungal Biodiversity Institute, Utrecht, The Netherlands (=CBS $\left.13945^{\mathrm{T}}\right)$ and in the 250 German Collection of Microorganisms and Cell Cultures, Braunschweig, Germany (DSM $\left.251 \quad 104832^{\mathrm{T}}\right)$.

252 Strain examined: $\mathrm{PC}^{\mathrm{T}}{ }^{\mathrm{T}}$, SNB-CN72 (= DSM 104833), IBL 03150

253

\section{DISCUSSION}

255 Morphological and physiological characteristics of the three yeast isolates examined in this study 256 are uniform, differences in ITS and LSU sequences are low all that suggesting assignment to a 257 single species. Molecular phylogenetic analyses reveal the three yeast isolates within the 
258 Graphiolaceae as a sister lineage of Graphiola cylindrica, G. geonomae, and G. phoenicis. Thus, 259 we propose Graphiola fimbriata sp. nov. to accommodate the three yeast strains. On the basis of 260 the pair-wise sequence similarities (ITS and D1/D2 regions) and subsequence phylogenetic 261 analyses (Figs 1 \& 2), the novel species differs from all other Graphiola species.

262 We also emend the description of the genus Graphiola to allow the inclusion of species known 263 from saprobic state only (see Taxonomy section).

264 The ecology and distribution range of the novel species is unknown. All described Graphiola 265 species are plant pathogens on palms (Arecaceae). We hypothesize that the novel species is 266 probably associated with plants, as also suggested by the origin of the studied isolates and 267 closely related culture Exobasidiomycetidae sp. AUMC 10262 (KX011608) from the palm 268 weevil Rhynchophorus ferrugineus that infests palms, which is a primary host of Graphiola. 269 Although the novel species is known from its asexual state, it is most likely that it has a host like 270 all other Graphiola species. Widespread transcontinental transfer of plants results in a global 271 dissemination of plant pathogens and crop pests (Bebber 2015, Hurley et al. 2016). Among them, 272 fungal pathogens currently lead the global invasion of agriculture, despite their more restricted 273 host range (Bebber et al. 2014, Wingfield et al. 2017). In our study, a new species of the plant 274 pathogenic genus Graphiola was identified over a broad geographic range that includes the Old 275 World (Iran and Egypt), tropical Asia and the Americas (French Guiana and USA). It is very 276 likely that the ongoing transport of plants and pests promoted dissemination of Graphiola 277 fimbriata between continents, localities, and habitats.

278 It cannot be precluded that Graphiola fimbriata represents the anamorphic stage of a palm 279 pathogen of which no sequence data are available. Of the 12 Graphiola species described 280 (Piepenbring et al. 2012) only three are represented by sequence data in GenBank. Moreover 
281 species diversity seems underestimated in the genus Graphiola. Assuming that its host 282 specificity developed to the same degree shown for other plant pathogens (Piątek et al. 2013, 283 Savchenko et al. 2014, Vasighzadeh et al. 2014, Choi \& Thines 2015, Scholler et al. 2016), the 284 number of 12 Graphiola species on 38 palm species from 21 plant genera (Farr \& Rossman n.d., 285 Piepenbring et al. 2012) is lower than in other known plant-parasite systems. Intensive sampling 286 and molecular analyses were used successfully in other groups to link anamorph and teleomorph 287 stages (Sampaio 2004, Boekhout et al. 2006, Inácio et al. 2008, Wang et al. 2015a, Kruse et al. 288 2017, Piątek et al. 2017). However, both sexual and asexual species are yet strongly under 289 sampled in many lineages (Liu et al. 2015a, Wang et al. 2015a, Wang et al. 2015b). Although 290 291 292 these studies unified systematics of plant parasites and yeast taxa, the results strongly suggest that the available genetic data is insufficient to resolve anamorph-teleomorph relationships in sister lineages (e.g., Boekhout et al. 2006, Kruse et al. 2017).

293 The lack of sequence data of sexual species also complicates biodiversity assessments and new 294 species discovery. With this study we provide the first overview on Graphiola diversity from 295 sequence data available in public databases. We propose new species Graphiola fimbriata to 296 accommodate yeasts from several localities and habitats. Our results show that sequences related 297 to Graphiola species are rapidly accumulating in public databases as taxonomically unassigned 298 isolates and clones. In our opinion, it is important to describe Graphiola fimbriata to provide a 299 proper name for these isolates to communicate it in the future. We agree that taxonomic 300 redundancy cannot be ruled out in the genus Graphiola considering a very few sequenced 301 species. Rediscovery and description of already known species as new may happen when stable 302 and informative morphological characters for species differentiation are limited, both in plant 303 material and in culture. Thus, future studies should be addressed on resampling and sequencing 
of new and already existing material in order to better understand genetic diversity and taxonomy

305 in this group of fungi.

306 There is little known about physiological properties of dimorphic plant parasites, whereas fungi 307 traditionally recognized as "yeasts" were intensively studied in this respect. Undersampling and 308 the lack of genetic (including housekeeping genes) and physiological data do not allow 309 delimitation of many genera (e.g., Wang et al. 2015a). In this study, we decided not to propose a 310 new genus for the novel fungus, but to accommodate it in the genus Graphiola in order to reduce 311 the taxonomic complexity in this group. Neither phylogenetic analyses nor the analysis of 312 physiological data revealed a basis to distinguish the new species from other Graphiola species. 313 Therefore, we modified the description of the genus Graphiola to include information about its 314 asexual form considering own results and previous reports by Tubaki \& Yokohama (1971) and 315 Oberwinkler et al. (1982). Despite limited genetic data, our study identified several fungal 316 isolates and metabarcoding clones as Graphiola fimbriata and G. phoenicis (Figs. 1 \& 2). These 317 fungi were found in Indomalayan and Neotropical realms (e.g., Takashima et al. 2012, Urbina et 318 al. 2016), which are the regions where palms are widely distributed (Kissling et al. 2012).

\section{ACKNOWLEDGEMENTS}

320 This work has benefited from an "Investissement d'Avenir" grant managed by the Agence 321 Nationale de la Recherche (CEBA, ref ANR-10-LABX-0025). The authors are grateful to C. 322 Nirma for isolating SNB-CN72 and to R. Constantino for identification of the host termite. The 323 authors gratefully acknowledge financial support from the Iranian Biological Resource Centre 324 (IBRC), ACECR. Authors are grateful to Prof. M. Catherine Aime (Purdue University, USA) 325 and Dr. Marizeth Groenewald (Westerdijk Fungal Biodiversity Institute, The Netherlands) for 326 granting access to the strain IBL 03150. 
CONFLICTS OF INTEREST

330 The authors declare that there are no conflicts of interest.

\section{LITERATURE CITED}

Albu S, Toome M, Aime MC (2015). Violaceomyces palustris gen. et sp. nov. and a new monotypic lineage, Violaceomycetales ord. nov. in Ustilaginomycetes. Mycologia 107: 1193-1204

Altschul SF, Madden TL, Schäffer AA, Zhang J, Zhang Z, Miller W, Lipman DJ (1997). Gapped BLAST and PSI-BLAST: a new generation of protein database search programs. Nucleic Acids Res 25: 3389-3402

Barnett JA, Payne RW, Yarrow D (2000). Yeasts: Characteristics and Identification. 3rd edn. Cambridge University Press, Cambridge

342 Bebber DP (2015). Range-expanding pests and pathogens in a warming world. Annu Rev Phytopathol 53: 335-356

Bebber DP, Holmes T, Gurr SJ (2014). The global spread of crop pests and pathogens. Glob Ecol Biogeogr 23: 1398-1407 sequences of smut fungi and related taxa. Can J Bot 75: 2045-2056 anamorphs as deduced from nuclear LSU rDNA sequences. Mycol Res 104: 53-60 
Begerow D, Bauer R, Oberwinkler F (2001). Muribasidiospora: Microstromatales or Exobasidiales? Mycol Res 105: 798-810

Begerow D, Bauer R, Oberwinkler F (2002). The Exobasidiales: An evolutionary hypothesis. Mycol Prog 1: 187-199

Begerow D, Schäfer AM, Kellner R, Yurkov A, Kemler M, Oberwinkler F, Bauer R (2014). Ustilaginomycotina. In: McLaughlin DJ, Spatafora JW (eds) The Mycota, systematics and evolution, vol. 7A. Springer, Berlin, pp 299-330

Begerow D, Kemler M, Feige A, Yurkov A (2017). Parasitism in Yeasts. In: Buzzini P, Lachance MA, Yurkov A (eds) Yeasts in Natural Ecosystems: Ecology. Springer, Cham, pp 179-210

Boekhout T, Theelen B, Houbraken J, Robert V, Scorzetti G, Gafni A, Gerson U, Sztejnberg A (2003). Novel anamorphic mite-associated fungi belonging to the Ustilaginomycetes: Meira geulakonigii gen. nov., sp. nov., Meira argovae sp. nov. and Acaromyces ingoldii gen. nov., sp. nov. Int J Syst Evol Microbiol 53: 1655-1664

Boekhout T, Gildemacher P, Theelen B, Müller WH, Heijne B, Lutz M (2006). Extensive colonization of apples by smut anamorphs causes a new postharvest disorder. FEMS Yeast Res 6: 63-76

Boekhout T, Fonseca Á, Sampaio JP (2011). Discussion of teleomorphic and anamorphic basidiomycetous yeasts. In: Kurtzman CP, Fell JW, Boekhout T, editors. The yeasts, a taxonomic study. 5th edn. Elsevier; Amsterdam: 2011.pp. 1339-1372. 
370 Castlebury LA, Carris LM, Vánky K (2005). Phylogenetic analysis of Tilletia and allied genera

371

372

373

374

375

376

377

378

379

380

381

382 in order Tilletiales (Ustilaginomycetes; Exobasidiomycetidae) based on large subunit nuclear rDNA sequences. Mycologia 97: 888-900

Castresana J (2000). Selection of conserved blocks from multiple alignments for their use in phylogenetic analysis. Mol Biol Evol 17: 540-552

Choi Y-J, Thines M (2015). Host jumps and radiation, not co-divergence drives diversification of obligate pathogens. A case study in downy mildews and Asteraceae. PloS One 10: $\mathrm{e} 0133655$

Dunthorn M, Kauserud H, Bass D, Mayor J, Mahé F (2017). Yeasts dominate soil fungal communities in three lowland Neotropical rainforests. Environ Microbiol Rep 9: 668-675

Farr DF, Rossman AY (n.d.). Fungal Databases, U.S. National Fungus Collections, ARS, USDA. Retrieved April 18, 2018, from https://nt.ars-grin.gov/fungaldatabases/

Gatesy J, DeSalle R, Wheeler W (1993). Alignment-ambiguous nucleotide sites and the exclusion of systematic data. Mol Phylogenet Evol 2: 152-157

Giribet G, Wheeler WC (1999). On gaps. Mol Phylogenet Evol 13: 132-143

Guo LD, Hyde KD, Liew EC (2001). Detection and taxonomic placement of endophytic fungi within frond tissues of Livistona chinensis based on rDNA sequences. Mol Phylogenet Evol 20: 1-13

Hanna M, Xiao W (2006). Isolation of nucleic acids. In: Xiao W (ed) Yeast Protocols (Methods in Molecular Biology), Volume 313. Humana Press, pp. 15-20

Hurley BP, Garnas J, Wingfield MJ, Branco M, Richardson DM, Slippers B (2016). Increasing numbers and intercontinental spread of invasive insects on eucalypts. Biol Invasions 18: $921-933$ 
Inácio J, Landell MF, Valente P, Wang PH, Wang YT, Yang SH, Manson JS, Lachance MA, Rosa CA, Fonseca Á (2008). Farysizyma gen. nov., an anamorphic genus in the Ustilaginales to accommodate three novel epiphytic basidiomycetous yeast species from America, Europe and Asia. FEMS Yeast Res 8: 499-508

Jimu L, Kemler M, Mujuru L, Mwenje E (2017). Illumina DNA metabarcoding of Eucalyptus plantation soil reveals the presence of mycorrhizal and pathogenic fungi. Forestry 19: 1-8

Jusino MA, Lindner DL, Banik MT, Walters JR (2015). Heart rot hotel: fungal communities in red-cockaded woodpecker excavations. Fungal Ecol 14: 33-43

Katoh K, Standley DM (2013). MAFFT multiple sequence alignment software version 7: improvements in performance and usability. Mol Biol Evol 30: 772-780

Kijpornyongpan T, Aime MC (2016). Rare or rarely detected? Ceraceosorus guamensis sp. nov.: a second described species of Ceraceosorales and the potential for underdetection of rare lineages with common sampling techniques. Antonie van Leeuwenhoek 109: 1127-1139

Kissling WD, Eiserhardt WL, Baker WJ, Borchsenius F, Couvreur TL, Balslev H, Svenning JC (2012). Cenozoic imprints on the phylogenetic structure of palm species assemblages worldwide. Proc Natl Acad Sci USA 109: 7379-7384

Kruse J, Doehlemann G, Kemen E, Thines M (2017). Asexual and sexual morphs of Moesziomyces revisited. IMA Fungus 8: 117-129

Kurtzman CP, Boekhout T (2017). Yeasts as Distinct Life Forms of Fungi. In: Buzzini P, Lachance MA, Yurkov A (eds) Yeasts in Natural Ecosystems: Ecology. Springer, Cham, pp 1-37

Kurtzman CP, Fell JW, Boekhout T (2011). The yeasts, a taxonomic study, 5th edn. Elsevier Science Publication, Amsterdam 
Kurtzman CP, Robnett CJ (1998). Identification and phylogeny of ascomycetous yeasts from analysis of nuclear large subunit (26S) ribosomal DNA partial sequences. Antonie van Leeuwenhoek 73: 331-371

Kurtzman CP, Mateo RQ, Kolecka A, Theelen B, Robert V, Boekhout T (2015). Advances in yeast systematics and phylogeny and their use as predictors of biotechnologically important metabolic pathways. FEMS Yeast Res 15: fov050

Liu XZ, Wang QM, Göker M, Groenewald M, Kachalkin AV, Lumbsch HT, Millanes AM, Wedin M, Yurkov AM, Boekhout T, Bai FY (2015a). Towards an integrated phylogenetic classification of the Tremellomycetes. Stud Mycol 81: 85-147

Liu XZ, Wang QM, Theelen B, Groenewald M, Bai FY, Boekhout T (2015b). Phylogeny of tremellomycetous yeasts and related dimorphic and filamentous basidiomycetes reconstructed from multiple gene sequence analyses. Stud Mycol 81: 1-26

Nasanit R, Tangwong-O-Thai A, Tantirungkij M, Limtong S (2015). The assessment of epiphytic yeast diversity in sugarcane phyllosphere in Thailand by culture-independent method. Fungal Biol 119: 1145-1157

Nasr S, Soudi MR, Shahzadeh Fazeli SA, Nguyen HDT, Lutz M, Piątek P (2014). Expanding evolutionary diversity in the Ustilaginomycotina: Fereydouniaceae fam. nov. and Fereydounia gen. nov., the first urocystidalean yeast lineage. Mycol Prog 13:1012

Nirma C, Eparvier V, Stien D (2013). Antifungal agents from Pseudallescheria boydii SNBCN73 isolated from a Nasutitermes sp. termite. J Nat Prod 76: 988-991

Nirma C, Eparvier V, Stien D (2015). Antibacterial ilicicolinic Acids C and D and ilicicolinal from Neonectria discophora SNB-CN63 isolated from a termite nest. J Nat Prod 78: 159162 
Oberwinkler F, Bandoni RJ, Blanz P, Deml G, Kisimova-Horovitz L (1982). Graphiolales: Basidiomycetes parasitic on palms. P1 Syst Evol 140: 251-277

Piątek M, Lutz M, Chater AO (2013). Cryptic diversity in the Antherospora vaillantii complex on Muscari species. IMA Fungus 4: 5-19

Piątek M, Lutz M, Sousa FMP, Santos ARO, Félix CR, Landell MF, Gomes FCO, Rosa CA (2017). Pattersoniomyces tillandsiae gen. et comb. nov.: linking sexual and asexual morphs of the only known smut fungus associated with Bromeliaceae. Org Divers Evol 17: $531-543$

Piątek M, Lutz M, Yorou NS (2015). A molecular phylogenetic framework for Anthracocystis (Ustilaginales), including five new combinations (inter alia for the asexual Pseudozyma flocculosa), and description of Anthracocystis grodzinskae sp. nov. Mycol Prog 14: 88

Piepenbring M, Espinoza J, Saldaña L, Cáceres O (2010). New records, host plants, morphological and molecular data of Exobasidiales (Basidiomycota) from Panama. Nova Hedwigia 91: 231-242

Piepenbring M, Nold F, Trampe T, Kirschner R (2012). Revision of the genus Graphiola (Exobasidiales, Basidiomycota). Nova Hedwigia 94: 67-96

Posada F, Aime MC, Peterson SW, Rehner SA, Vega FE (2007). Inoculation of coffee plants with the fungal entomopathogen Beauveria bassiana (Ascomycota: Hypocreales). Mycol Res 111: 748-757

Richards TA, Jones MD, Leonard G, Bass D (2012). Marine fungi: their ecology and molecular diversity. Ann Rev Mar Sci 4: 495-522 
478

479 480 481

Sampaio JP (2004). Diversity, phylogeny and classification of basidiomycetous yeasts. In: Agerer R, Blanz P, Piepenbring M (eds) Frontiers in Basidiomycote Mycology. IHWVerlag, Eching, pp 49-80

Savchenko KG, Carris LM, Castlebury LA, Heluta VP, Wasser SP, Nevo E (2014). Revision of Entyloma (Entylomatales, Exobasidiomycetes) on Eryngium. Mycologia 106: 797-810

Scholler M, Schmidt A, Siahaan SAS, Takamatsu S, Braun U (2016). A taxonomic and phylogenetic study of the Golovinomyces biocellatus complex (Erysiphales, Ascomycota) using asexual state morphology and rDNA sequence data. Mycol Prog 15: 56

Sipiczki M, Kajdacsi E (2009). Jaminaea angkorensis gen. nov., sp. nov., a novel anamorphic fungus containing an S943 nuclear small-subunit rRNA group IB intron represents a basal branch of Microstromatales. Int J Syst Evol Microbiol 59: 914-920

Stoll M, Begerow D, Oberwinkler F (2005). Molecular phylogeny of Ustilago, Sporisorium, and related taxa based on combined analyses of rDNA sequences. Mycol Res 109: 342-356

Sugiyama J, Tokuoka K, Suh SO, Hirata A, Komagata K (1991). Sympodiomycopsis: a new yeast-like anamorph genus with basidiomycetous nature from orchid nectar. Antonie van Leeuwenhoek 59: 95-108

Takashima M, Sugita T, Van BH, Nakamura M, Endoh R, Ohkuma M (2012). Taxonomic richness of yeasts in Japan within subtropical and cool temperate areas. PLoS One 7: e50784

Tanaka E, Shimizu K, Imanishi Y, Yasuda F, Tanaka C (2008). Isolation of basidiomycetous anamorphic yeast-like fungus Meira argovae found on Japanese bamboo. Mycoscience 49: $329-333$ 
Tubaki K, Yokoyama T (1971). Cultural aspects of Graphiola phoenicis. Mycopath Mycol Appl 43: 49-60

Urbina H, Scofield DG, Cafaro M, Rosling A (2016). DNA-metabarcoding uncovers the diversity of soil-inhabiting fungi in the tropical island of Puerto Rico. Mycoscience 57: $217-227$

Van Wyk PWJ, Wingfield MJ (1994). Ultrastructure of ascus arrangement and ascospore development in Ophiostoma seticolle. Mycologia 86: 607-614

Vasighzadeh A, Zafari D, Selçuk F, Hüseyin E, Kurşat M, Lutz M, Piątek M (2014). Discovery of Thecaphora schwarzmaniana on Rheum ribes in Iran and Turkey: implications for the diversity and phylogeny of leaf smuts on rhubarbs. Mycol Prog 13: 881-892

Wingfield MJ, Slippers B, Wingfield BD, Barnes I (2017). The unified framework for biological invasions: a forest fungal pathogen perspective. Biol Invasions. 19: 3201-3214

Wang QM, Theelen B, Groenewald M, Bai FY, Boekhout T (2014). Moniliellomycetes and Malasseziomycetes, two new classes in Ustilaginomycotina. Persoonia 33: 41-47

Wang QM, Begerow D, Groenewald M, Liu XZ, Theelen B, Bai FY, Boekhout T (2015a). Multigene phylogeny and taxonomic revision of yeasts and related fungi in the Ustilaginomycotina. Stud Mycol 81: 55-83

Wang QM, Groenewald M, Takashima M, Theelen B, Han PJ, Liu XZ, Boekhout T, Bai FY (2015b). Phylogeny of yeasts and related filamentous fungi within Pucciniomycotina determined from multigene sequence analyses. Stud Mycol 81: 27-53

Wang QM, Yurkov AM, Göker M, Lumbsch HT, Leavitt SD, Groenewald M, Theelen B, Liu XZ, Boekhout T, Bai FY (2015c). Phylogenetic classification of yeasts and related taxa within Pucciniomycotina. Stud Mycol 81: 149-189 
White TJ, Bruns TD, Lee S, Taylor JW (1990). Amplification and direct sequencing of fungal ribosomal RNA genes for phylogenetics. In: Innis MA, Gelfand DH, Sninsky JJ, White TJ (eds) PCR Protocols: a guide to methods and applications. Academic Press, San Diego, pp 315-322

Yasuda F, Yamagishi D, Akamatsu H, Izawa H, Kodama M, Otani H (2005). Fruit stain of Japanese pear caused by basidiomycetous, yeast-like fungi, Acaromyces ingoldii and Meira sp. Jpn J Phytopathol 71: 156-165

Yasuda F, Yamagishi D, Akamatsu H, Izawa H, Kodama M, Otani H (2006). Meira nashicola sp. nov., a novel basidiomycetous, anamorphic yeastlike fungus isolated from Japanese pear fruit with reddish stain. Mycoscience 47: 36-40

Yuan ZL, Rao LB, Chen YC, Zhang CL, Wu YG (2011). From pattern to process: species and functional diversity in fungal endophytes of Abies beshanzuensis. Fungal Biol 115: 197213

\section{TABLES}

Table 1. Designations and GenBank accession numbers of the yeast strains used in this study.

\begin{tabular}{|c|c|c|c|c|}
\hline \multirow{2}{*}{ Yeast strains } & \multicolumn{2}{|c|}{ Strain designation } & \multicolumn{2}{c|}{ GenBank accession numbers } \\
\cline { 2 - 5 } & IBRC-M & CBS & LSU & ITS \\
\hline PC1 & $30158^{\mathrm{T}}$ & $13945^{\mathrm{T}}$ & KM403453 & KM403454 \\
\hline SNB-CN72 & 30163 & - & KP229360 & KJ023736 \\
\hline IBL 03150 & - & 14052 & KP308195 & DQ682574 \\
\hline
\end{tabular}




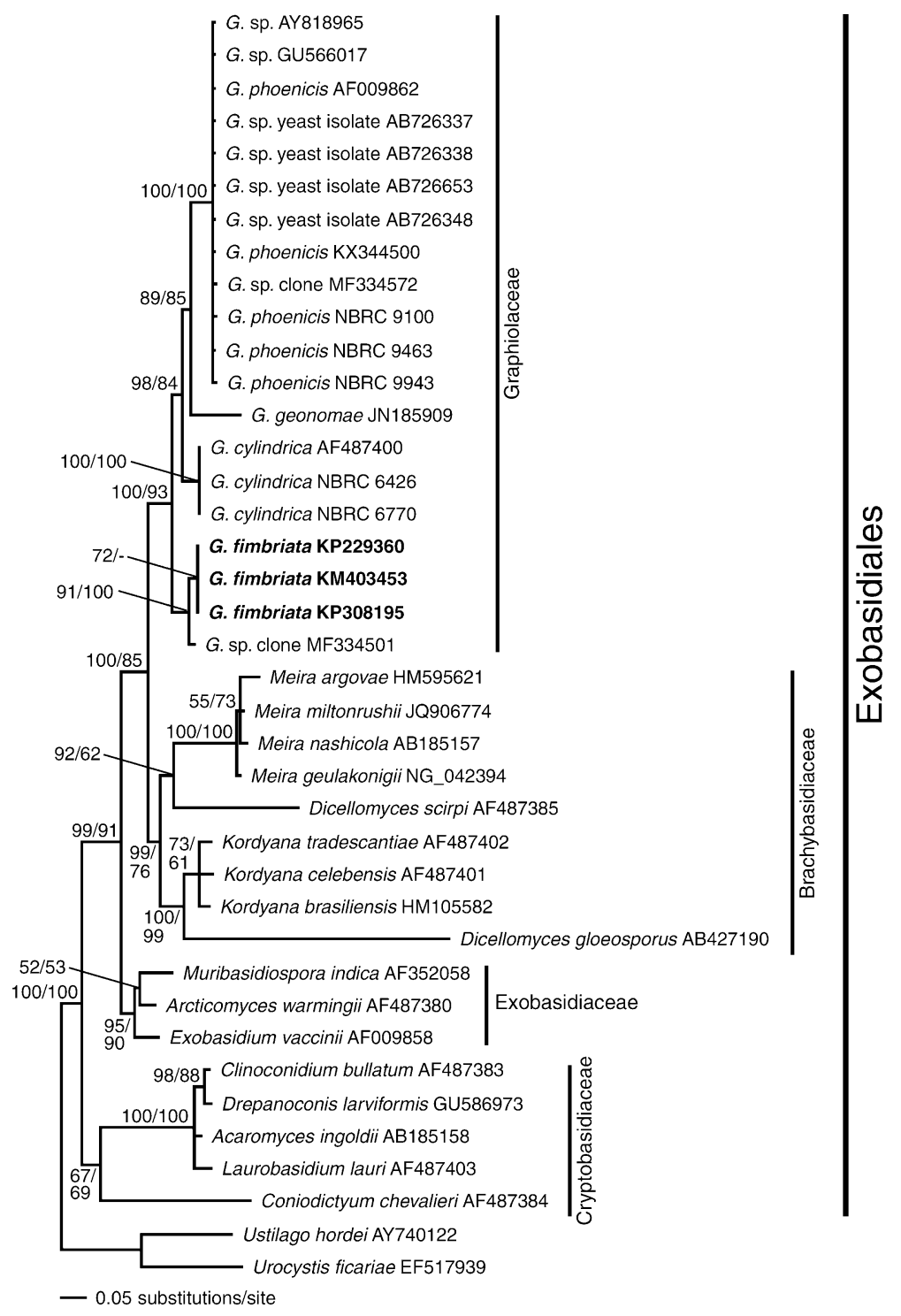

526 Fig. 1. Bayesian inference of phylogenetic relationships within the sampled Exobasidiales:

527 Markov chain Monte Carlo analysis of an alignment of LSU base sequences using the GTR $+\mathrm{I}+\mathrm{G}$

528 model of DNA substitution with gamma distributed substitution rates and estimation of invariant

529 sites, random starting trees, and default starting parameters of the DNA substitution model. A

$53050 \%$ majority-rule consensus tree is shown computed from 75000 trees that were sampled after 
531 the process had become stationary. The topology was rooted with the ustilaginomycetous species

532 Urocystis ficariae and Ustilago hordei. Numbers on branches before slashes are estimates for a 533 posteriori probabilities; numbers on branches after slashes are ML bootstrap support values.

534 Branch lengths were averaged over the sampled trees. They are scaled in terms of expected 535 numbers of nucleotide substitutions per site. The taxonomical concept applied corresponds to 536 Begerow et al. (2014).

537 


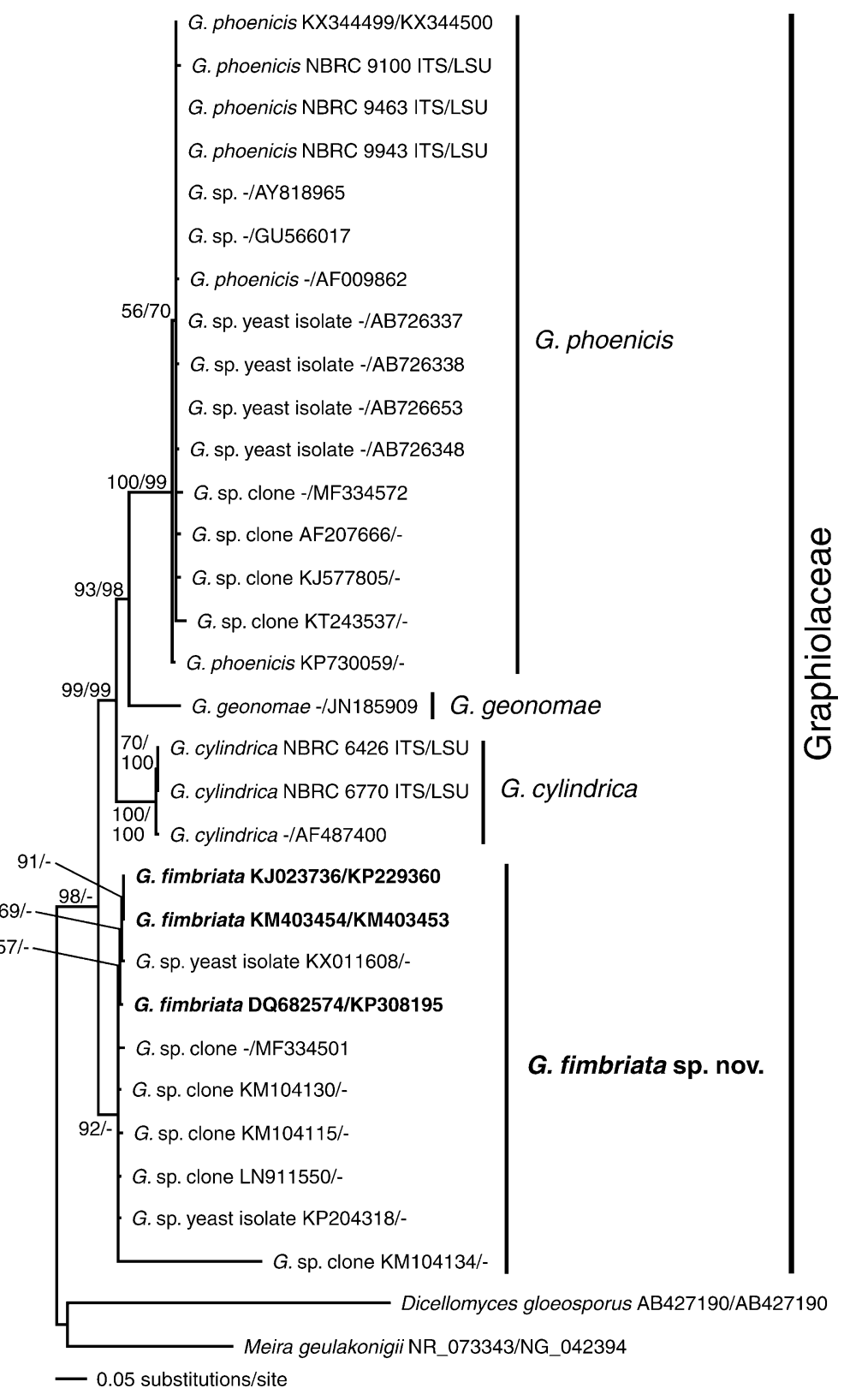

539 Fig. 2. Bayesian inference of phylogenetic relationships within the sampled Exobasidiales:

540 Markov chain Monte Carlo analysis of an alignment of ITS+LSU base sequences using the 541 GTR $+\mathrm{I}+\mathrm{G}$ model of DNA substitution with gamma distributed substitution rates and estimation 542 of invariant sites, random starting trees, and default starting parameters of the DNA substitution 543 model. A 75\% majority-rule consensus tree is shown computed from 75000 trees that were 544 sampled after the process had become stationary. The topology was rooted with the 
545 cryptobasidiaceous species Acaromyces ingoldii and Clinoconidium sp. Numbers on branches 546 before slashes are estimates for a posteriori probabilities; numbers on branches after slashes are 547 ML bootstrap support values. Branch lengths were averaged over the sampled trees. They are 548 scaled in terms of expected numbers of nucleotide substitutions per site. The taxonomical 549 concept applied corresponds to Begerow et al. (2014).

550
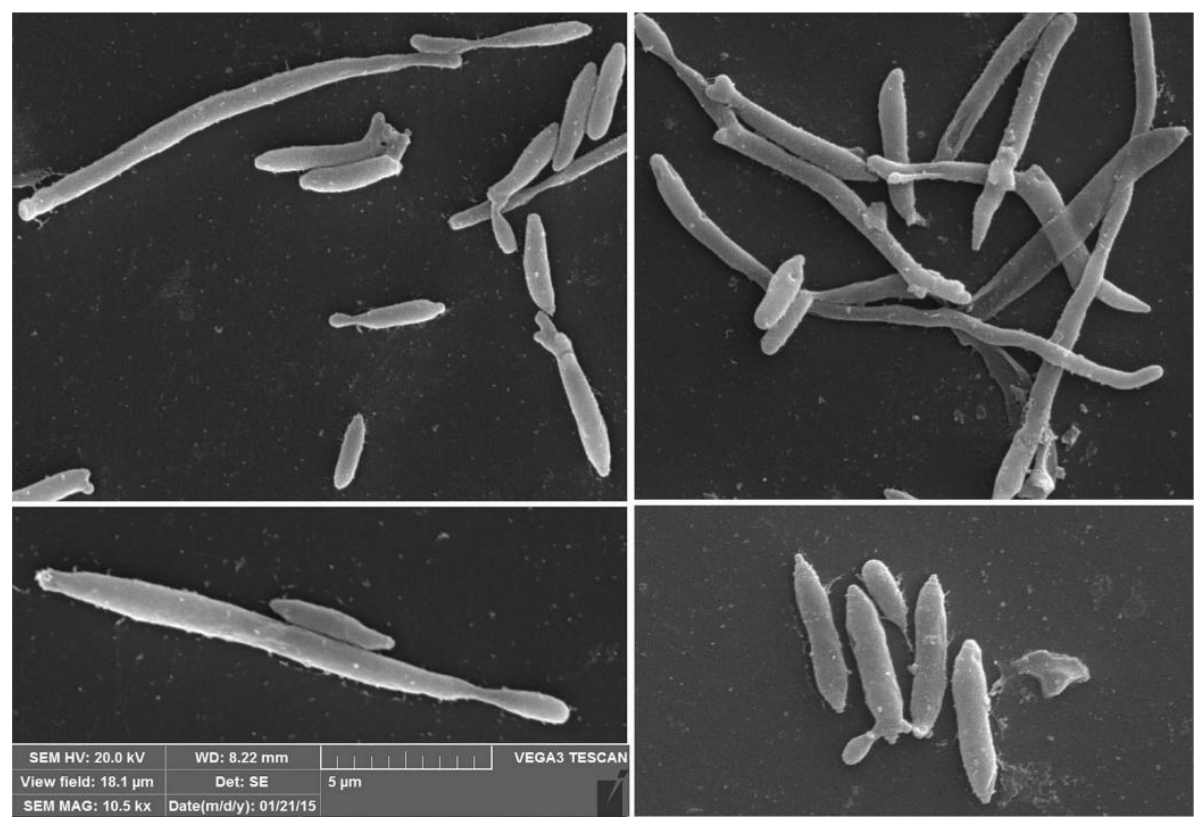

552 Fig. 3. Scanning electron micrographs of the strain IBRC-M $30158^{\mathrm{T}}$ showing budding cells and 553 bud scars. Scale bars: $5 \mu \mathrm{m}$. 